\title{
Functional diversity of soil microbial communities in boreal and temperate Scots pine forests
}

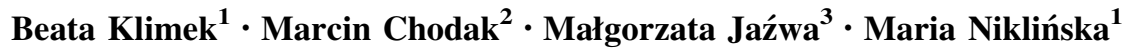

Received: 11 December 2015/Revised: 15 May 2016/Accepted: 19 May 2016/Published online: 1 June 2016

(C) The Author(s) 2016. This article is published with open access at Springerlink.com

\begin{abstract}
Scots pine (Pinus sylvestris L.) is one of the most widespread conifer species in Europe, able to tolerate a wide variety of climatic conditions. The aim of the study was to compare the activity, functional diversity and community-level physiological profiles (CLPPs) of soil microorganisms in Scots pine forests of the boreal and temperate climatic zones. The soil samples were taken from the $\mathrm{O}$ and A soil horizons in northern Finland (boreal pine forest, BP) and Poland (dry and mesic temperate pine forest, TDP and TMP, respectively) and measured for water-holding capacity, $\mathrm{pH}$, organic $\mathrm{C}$, dissolved organic $\mathrm{C}$ (DOC) and the total contents of N, P, Ca, Mg, K, Na and $\mathrm{Mn}$. The microbial activity (multiple substrate-induced respiration rate) and functional diversification (communitylevel physiological profiles, CLPPs) were assessed using the MicroResp ${ }^{\text {TM }}$ system with 22 different $\mathrm{C}$ substrates. The BP soils were finer textured and contained more $\mathrm{Ca}, \mathrm{K}$, $\mathrm{Mg}, \mathrm{Mn}$ and $\mathrm{Na}$ but less $\mathrm{N}$ and $\mathrm{P}$ than the soils under the temperate forests. The $\mathrm{pH}$ values did not differ between the studied forests. The studied pine forests did not differ in the measured microbial properties in the $\mathrm{O}$ horizon. However,
\end{abstract}

Communicated by Dr. Jarmo Holopainen.

Beata Klimek

beata.klimek@uj.edu.pl

1 Institute of Environmental Sciences, Faculty of Biology and Earth Sciences, Jagiellonian University, Gronostajowa 7, 30-387 Kraków, Poland

2 Department of Management and Protection of Environment, AGH University of Science and Technology, Al. Mickiewicza 30, 30-059 Kraków, Poland

3 Institute of Botany, Faculty of Biology and Earth Sciences, Jagiellonian University, Kopernika 27, 31-501 Kraków, Poland in the A horizon, the microorganisms from the BP soil were less active and less functionally diverse than those from the temperate forest soils. The CLPPs of the BP soils differed from those of the temperate forest soils, wherein the largest difference was from the use of carboxylic acids and amino acids. The microorganisms from the BP soils used carboxylic acids more efficiently but were much less efficient in decomposing amino acids than those from the temperate forest soils. These differences were related to the contents of DOC, $\mathrm{N}$ and $\mathrm{P}$ which are influenced by climate and bedrock properties. Our results indicate that soil microbial properties in the $\mathrm{O}$ horizon depend mainly on the vegetation, whereas in deeper layers, they depend to a larger extent on bedrock properties and climatic conditions.

Keywords CLPP $\cdot$ MicroResp ${ }^{\mathrm{TM}} \cdot$ Functional microbial diversity · Podzols · Pinus sylvestris L.

\section{Introduction}

Soil microorganisms are essential drivers of nutrient turnover in terrestrial ecosystems, being involved in numerous key soil processes including organic matter degradation, mineralisation and humification (Bauhus and Khanna 1999; Wardle et al. 2004). The functional diversity of soil microbial communities is regulated by physico-chemical soil properties, climate, as well as the composition of plant cover (Grayston et al. 2004; Ladygina and Hedlund 2010; Sherman and Steinberger 2012). In forest ecosystems, the dominating tree species influence the metabolic abilities of soil microbial communities by the production of litter of a specific chemical quality (Kiikkilä et al. 2006), root exudation (Attiwill and Adams 1993) and through affecting the 
chemical and physical soil properties (Bauhus et al. 1998; Menyailo et al. 2002).

The Scots pine (Pinus sylvestris) has been described as supporting the development of distinct microbial communities (Priha et al. 2001; Hackl et al. 2005; ZechmeisterBoltenstern et al. 2011; Kuramae et al. 2012). Hackl et al. (2005) and Zechmeister-Boltenstern et al. (2011) found higher abundance of fungal phospholipid fatty acids (PLFAs) in soils under pine forests than under forests with other dominant tree species (beech, oak, spruce, fir) and suggested that this was because fungi are more efficient than bacteria in the degradation of recalcitrant pine litter. Högberg and Högberg (2002) reported that ectomycorrhizal fungi constituted nearly one-third of microbial biomass in Scots pine forest soils in northern Sweden. The large share of ectomycorrhizal fungi in soil microbial communities under pine forests may lead to the development of microbial communities with specific functional abilities (Heinonsalo et al. 2001; Finlay 2008). Ectomycorrhizal fungi are known to exude low molecular mass organic acids (Ahonen-Jonnarth et al. 2000; van Breemen et al. 2000) and in this way may influence soil microbial communities and their metabolic preferences (Heinonsalo et al. 2001; Banning et al. 2012).

The Scots pine is one of the most widespread conifer species on Earth (Matías and Jump 2012). In Europe, pine stands cover $24 \%$ of forested area (Leski et al. 2010), spreading from Fennoscandia in the boreal climate zone to central and southern Europe in the temperate climate zone (Boratyński 1991; Kelly and Conolly 2000). In consequence, the microbial properties of pine forest soils may be variable. It is known that the interactions between the plant communities and soil microbial communities in forest ecosystems are often driven by abiotic factors such as the physico-chemical properties of soil parent materials (Thoms et al. 2010; Gartzia-Bengoetxea et al. 2016). Climatic conditions (temperature and precipitation regimes) may also affect soil microbial communities (Evans and Wallenstein 2014) by selection of specific microbial groups better adapted to local climatic conditions.

The functional diversity and structure of soil microbial communities are of particular importance for the functioning of soils (Zak et al. 1994) since the soil organic matter transformation rate depends on the ability of microbial communities to metabolise different organic compounds (Garcia-Pausas and Paterson 2011). Therefore, information on the metabolic abilities of microbial communities under Scots pine forests of boreal and temperate zones is essential for understanding how these forest ecosystems function.

In this study, we applied the MicroResp ${ }^{\text {TM }}$ method (Campbell et al. 2003) to compare the functional structure and functional diversity of soil microbial communities under Scots pine forests growing in the boreal and temperate climate zones.

\section{Materials and methods}

\section{Study sites}

The study sites were located in the boreal climate zone in Finland, the Scandinavian Peninsula and in the temperate climate zone in Poland, an East-Central European country (Fig. 1). The sampling plots were chosen to be representative of the prevailing climatic conditions (boreal and temperate) and dominating tree species (Scots pine) and comprised only natural forest stands developed without, or with only minimal, forest management.

The boreal pine forest stands (BP) $(N=5)$ included Vaccinium type (VT) with understory dominated by Vaccinium vitis-idaea and Empetrum nigrum representative of sub-dry forest types (Tonteri et al. 1990). They were located in the region of Oulanka National Park, close to the Arctic Circle, with a mean annual precipitation of $550 \mathrm{~mm}$

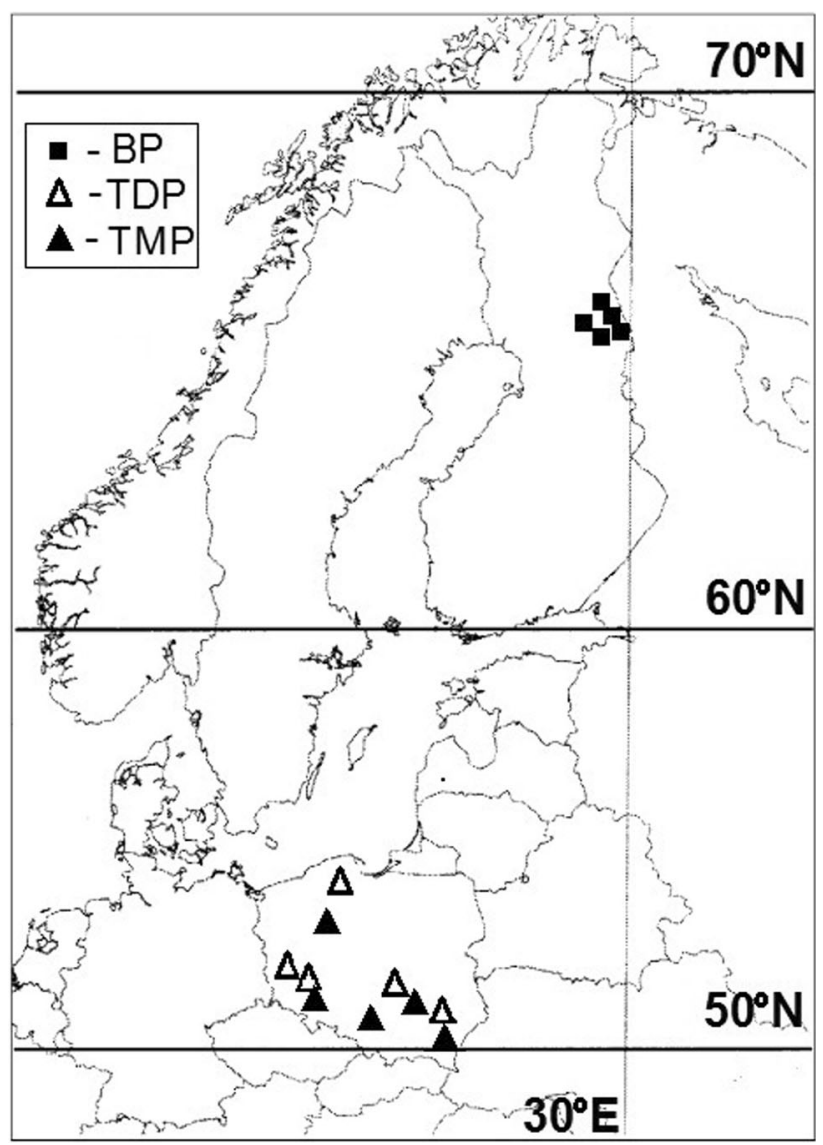

Fig. 1 Distribution of sampling sites for the boreal (BP), dry temperate (TDP) and mesic temperate pine (TMP) forest soils 
and a mean annual temperature of $-0.8^{\circ} \mathrm{C}$. The sampling area extended over ca. $560 \mathrm{~km}^{2}$, and the distance between the nearest sites representing BP forests was ca. $7 \mathrm{~km}$. At all sampling sites in the boreal forests, the soils were classified as podzols (FAO classification) developed from sandy materials. The depths of the $\mathrm{O}$ and $\mathrm{A}$ horizons in the BP forest soils averaged 7.5 and $4.5 \mathrm{~cm}$, respectively.

The temperate pine forest stands were located in different sites in Poland (Fig. 1), with the mean annual temperature ranging from 6.5 to $8.5^{\circ} \mathrm{C}$ and an average annual precipitation of ca. $550-750 \mathrm{~mm}$. The temperate pine forests included dry pine forest type (TDP) $(N=5)$-associations of Cladonio-Pinetum and Vaccinio-Pinetum, with typical poor forest floor with Cladonia lichens, and mesic pine forest type (TMP) $(\mathrm{N}=5)$-associations of Peucedano-Pinetum and Leucobryo-Pinetum (Matuszkiewicz 2006). Within both temperate pine forest types, five independent sites were sampled. The distance between the nearest sites representing the same forest type was ca. $50 \mathrm{~km}$ (Fig. 1). At all sampling sites in the temperate forests, the soils were classified as podzols (FAO classification) developed from sandy materials. In the TDP forest soils, the depth of the $\mathrm{O}$ horizon averaged $4.0 \mathrm{~cm}$ and of the A horizon $10.5 \mathrm{~cm}$. In the TMP forest soils, the mean depth of the $\mathrm{O}$ horizon was $5.7 \mathrm{~cm}$ and of the A horizon $13.0 \mathrm{~cm}$. There were 15 research sites altogether.

\section{Soil sampling}

The soil samples were collected during two sampling campaigns. The temperate pine forest soils were sampled in the first half of June 2013, and the boreal pine forest soils in the second half of July 2013. The duration of both sampling campaigns was one week. In Poland, the samples were packed in plastic boxes with air-permeable cover, placed in a portable cooling chamber and transported directly by car to our laboratory. In Finland, the soil samples were stored temporarily in the cooling chamber at the Oulanka Research Station.

One sample was collected using a steel core sampler on each site in the centre of a $100-\mathrm{m}^{2}$ plot used for botanical assessment, and four samples were collected from four corners around and bulked to obtain one mixed soil sample per plot, separately for the $\mathrm{O}$ and A soil horizons on each research site. These resulted in 15 soil samples of the $O$ horizon and, correspondingly, 15 soil samples of the A horizon (totally $N=30$ ).

Directly after collection, the samples were sieved (the $\mathrm{O}$ horizon through a $10-\mathrm{mm}$ sieve and the A horizon through a 2-mm sieve) to remove the green parts of the plants, stones and roots, packed into plastic boxes with air-permeable covers and transported field-moist to the laboratory, preventing heating by the use of cool bags during the day and storing in a fridge during the night (at a temperature ca. $4{ }^{\circ} \mathrm{C}$ ). Upon arrival at the laboratory, the samples were divided into two parts. One part was air-dried and used for physico-chemical analyses; the other part was stored at field-moist conditions at $4{ }^{\circ} \mathrm{C}$ for microbial analyses. The microbiological analyses begun around one month after collection of the sample set, so the storage time was the same for all samples. We treated all our samples in the same way in order not to introduce additional factors that could lead to different results in the studied soil groups.

\section{Soil physical and chemical analyses}

The soil dry weight (DW) was determined after drying the soil samples at $105^{\circ} \mathrm{C}$ for $24 \mathrm{~h}$. Water-holding capacity (WHC) was measured gravimetrically (Schlichting and Blume 1966). The soil $\mathrm{pH}$ was measured potentiometrically in water and in $1 \mathrm{M} \mathrm{KCl}$ solution $(1: 10 \mathrm{w} / \mathrm{v})$. The $\mathrm{C}$ and $\mathrm{N}$ contents were analysed using a CHNS analyser (Vario EL III, Elementar Analysensysteme GmbH). The total element ( $\mathrm{Ca}, \mathrm{K}, \mathrm{Mg}, \mathrm{Mn}, \mathrm{Na}$, and $\mathrm{P}$ ) concentrations in each soil sample were determined after wet digestion of $0.5 \mathrm{~g}$ of DW in $10 \mathrm{ml}$ of suprapure-concentrated $\mathrm{HNO}_{3}$ and $\mathrm{HClO}_{4}(7: 1 \mathrm{v} / \mathrm{v})$ (Sigma-Aldrich). The concentrations of the metals in the digests were measured using atomic absorption spectrometry (AAS) with a flame or graphite furnace nebuliser (PerkinElmer), and the $\mathrm{P}$ concentration was measured on a flow injection analyser (FIA compact, MLE). The accuracy of the mineralisation process was assessed using blank samples and samples of standard certified material (CRM025-050, Sandy Loam 8, RT Corp.). The concentration of dissolved organic carbon (DOC) was measured in water extracts obtained from $3 \mathrm{~g}$ of soil dry mass equivalent shaken for $1 \mathrm{~h}$ at 10:1 water-tosoil ratio at $200 \mathrm{rpm}$ (TOC-V $\mathrm{V}_{\mathrm{CPN}}$, Shimadzu). The texture of mineral soil fraction (A horizon) was assessed hydrometrically (Casagrande 1934). Each analysis was performed in three replicates; the data were averaged and expressed based on the dry weight of the soil.

\section{MicroResp ${ }^{\text {TM }}$ measurements}

The physiological abilities of pine forest soil microbial communities were determined using the MicroResp ${ }^{\mathrm{TM}}$ method (Campbell et al. 2003). The soils were adjusted to $40 \%$ of their maximum WHC and loaded into $1.2 \mathrm{ml}$ deep-well microtitre plates $(1.2 \mathrm{ml}$, Nunc, Thermo Electron LED, Langenselbold, Germany). The soil mass per well was ca. $0.35 \mathrm{~g} \mathrm{DW}$ for the A horizon samples and ca. $0.08 \mathrm{~g}$ DW for the O horizon. Subsequently, the samples were stored for 5 days at $22{ }^{\circ} \mathrm{C}$ before applying aqueous solutions of the different $\mathrm{C}$ sources and sealing the wells with a $\mathrm{CO}_{2}$ trap. 
The physiological profiles were determined by applying distilled water, 9 neutral sugars (D-glucose, D-fructose, D-galactose, D-maltose, D-xylose, D-arabinose, D-mannose, D-ribose and D-cellobiose), 5 amino acids ( $\gamma$ aminobutyric acid, L-alanine, L-arginine, L-lysine and Lproline), 2 amines (D-glucosamine and $\mathrm{N}$-acetyl-glucosamine), and 4 carboxylic acids (D-malic acid, L-ascorbic acid, $\alpha$-ketoglutaric acid and oxalic acid), one aromatic carboxylic acid (protocatechuic acid) and one polymer ( $\alpha$-cyclodextrin). The $\mathrm{C}$ compounds were chosen to represent plant root exudates and microbial products (McIntosh et al. 2013; Sradnick et al. 2013) with a large potential to discriminate different soil microbial communities (Banning et al. 2012). The substrates were added at a concentration of $8 \mathrm{mg} \mathrm{g}^{-1} \mathrm{DW}$ soil (Sradnick et al. 2013). Because of the low solubility at higher concentrations, only $0.8 \mathrm{mg} \mathrm{g}^{-1}$ DW soil of protocatechuic acid (3-4-dihydroxybenzoic acid) was applied. Each substrate was placed in 8 wells, giving 8 replicates for a sample. Application of the aqueous solutions increased soil moisture to ca. $60 \%$ of their maximum WHC.

The colorimetric detector plates were prepared as described by Campbell et al. (2003) and contained $12.5 \mu \mathrm{g} \mathrm{g}^{-1}$ cresol red, $150 \mathrm{mM} \mathrm{KCl}$ and $2.5 \mathrm{mM}$ $\mathrm{NaHCO}_{3}$ set in $1 \%$ Noble agar $(150 \mu \mathrm{l}$ per well $)$. The samples were incubated for $4 \mathrm{~h}$ at $25^{\circ} \mathrm{C}$. Absorbance of the detector plates was determined using a microplate reader at $572 \mathrm{~nm}$ ( $\mu$ Quant, Biotek, Winooski, Vermont, USA) immediately before sealing (T0) and after 4-h incubation (T1). A calibration curve of absorbance change (T1-T0) versus headspace $\mathrm{C}-\mathrm{CO}_{2}$ concentration $\left(0.20 \mu \mathrm{g} \mathrm{ml}^{-1}-10.50 \mu \mathrm{g} \mathrm{ml}^{-1}\right)$ was determined using gas mixtures with known $\mathrm{C}-\mathrm{CO}_{2}$ concentrations and fitted to an exponential decay model $\left(r^{2}=0.97\right)$. The use of particular $\mathrm{C}$ substrates by soil microbes was calculated by subtracting the basal respiration rates (water blanks) from the substrate-induced respiration values ( $\mu \mathrm{g} \mathrm{C}-\mathrm{CO}_{2} \mathrm{~g}^{-1} \mathrm{~h}^{-1}$ ) for particular substrates. The multiple substrate-induced respiration (MSIR) rate expressed in $\mu \mathrm{g} \mathrm{C}-\mathrm{CO}_{2} \mathrm{~g}^{-1} \mathrm{~h}^{-1}$ was used as a measure of total microbial activity in the tested soils. In order to compare metabolic preferences of the soil microbial communities, the CLPPs were based on the relative use of substrates. The relative use of a substrate was calculated by dividing the SIR value for a particular substrate by the total (summed) substrate response (MSIR) of each sample.

The microbial functional diversity index, derived from the Shannon-Wiener biodiversity index $\mathrm{H}_{\text {mic }}$, which is based on the structure of substrate use:

$H_{m i c}^{\prime}=-\sum_{i=1}^{s} p_{s} \log _{10} p_{s}$ was derived from the number of substrates $s$ and the utilisation of an individual substrate $p_{s}$ (Derry et al. 1999). Community-level physiological profiles (CLPPs) were expressed as the substrate-induced respiration rate values ( $\mu \mathrm{g} \mathrm{C}-\mathrm{CO}_{2} \mathrm{~g}^{-1} \mathrm{~h}^{-1}$ ) after subtracting the basal respiration values (water blanks), standardised to the sum of 1 within each soil sample.

\section{Statistical analyses}

Differences in the chemical, physical and microbial properties between the three forest types and two soil organic horizons were compared with one-way ANOVA with Tukey's test $(p<0.05)$, separately for the O and A horizons. Prior to the analysis, the data were checked for distribution normality and transformed if needed.

One-way analysis of similarities (ANOSIM) was used to test for significant differences in the CLPPs under the studied pine forest stands, separately for the $\mathrm{O}$ and $\mathrm{A}$ soil horizons (Clarke and Green 1988). ANOSIM is a nonparametric permutation procedure that compares betweengroup and within-group dissimilarities. This procedure calculates $\mathrm{R}$ statistic, wherein $R=0$ indicates a completely random grouping and $R=1$ only if all replicates within the groups are more similar to each other than any replicates across the groups. Global R-value was used to express overall dissimilarity between the stands. The significant global $\mathrm{R}$-values indicated that the $\mathrm{R}$-value differed significantly from 0 , suggesting that the compared sites were significantly dissimilar. Dissimilarities between the stands based on Bray-Curtis distances were tested in pairwise comparisons, and their significance was assessed according to the sequential Bonferroni correction. Similarity percentage (SIMPER) procedure was applied in order to identify which plant species or $\mathrm{C}$ substrates made the largest contribution to the average dissimilarity between the samples (Clarke 1993).

Canonical correspondence analysis (CCA) was used to link the microbial CLPPs to soil properties and to compare CLPPs under different forest types, separately for the $\mathrm{O}$ and A soil horizons (ter Braak 1987). In this analysis, we used the DOC content as a variable representing a readily available energy source for microbes; concentrations of $\mathrm{P}$ and $\mathrm{N}$, as well as C-to- $\mathrm{N}$ and $\mathrm{C}$-to-P ratios, as variables representing the availability of essential nutrients; $\mathrm{pH}$ in $\mathrm{KCl}$ as a variable representing soil acidity; and WHC as a variable approximating the ability of the soil to retain water.

The ANOVA analysis was performed using Statgraphics Centurion XVI (StatPoint Technologies Inc., Warrenton VA, USA) and the multivariate analyses with PAST 
software (Natural History Museum, University of Oslo, Norway).

\section{Results}

\section{Soil physical and chemical properties}

The mineral soils under the BP forests had the lowest share of sand fraction $(81.0 \%)$ and the highest share of silt fraction $(14.8 \%)$. The clay content was higher in the boreal soils $(4.2 \%)$ than in the temperate forest soils (1.6-2.6\%), but the difference was not statistically significant $(p=0.11)$. The highest sand content and the lowest silt content were under the TDP (93.3 and 5.2\%, respectively), whereas the TMP soils exhibited intermediate values (Table 1 ).

The soil A horizons of the BP forests were characterised by lower $\mathrm{N}$ and $\mathrm{P}$ contents than the temperate forests (however, the difference was statistically significant only between BP and TMP) (Table 2). In the $\mathrm{O}$ horizon, the $\mathrm{N}$ content was lower in the BP forests $\left(7.5 \mathrm{mg} \mathrm{g}^{-1} \mathrm{DW}\right)$ than in the temperate forests (8.9-9.9 $\left.\mathrm{mg} \mathrm{g}^{-1} \mathrm{DW}\right)$ but the difference was not statistically significant $(p=0.0694)$. The $\mathrm{P}$ content was similar in all the studied forests. In both studied horizons, the BP soils contained more $\mathrm{Ca}, \mathrm{K}, \mathrm{Mg}$, $\mathrm{Mn}$ and $\mathrm{Na}$ than the soils under the temperate forests (Table 2). There were no significant differences in soil $\mathrm{pH}$ between the studied forest soils. All the soils were acidic ( $\mathrm{pH}$ in water ranged from 3.6 to $4.4 ; \mathrm{pH}$ in $\mathrm{KCl}$ ranged from 2.7 to 3.8 ), wherein lower $\mathrm{pH}$ values were measured in the O horizon than in the A horizon (Table 2). The DOC contents in the $\mathrm{O}$ horizon did not differ between the studied forest types, but in the A horizon, the DOC content was significantly lower in the BP soils than in the temperate forest soils (Table 2).

\section{Microbial activity, functional diversity and community-level physiological profiles}

The MSIR and the $\mathrm{H}_{\text {mic }}$ values in the $\mathrm{O}$ horizon were similar for all the studied forests (Fig. 2). However, in the A horizon, BP forests were characterised by the lowest MSIR and $\mathrm{H}^{\prime}$ mic values and differed significantly $(p=0.0129)$ from the TMP forests, where these values were the highest. The values for TDP forest fell between these two forests (Fig. 2).

For the $\mathrm{O}$ soil horizon, the calculated $\mathrm{CCA}$ axes on CLPP pattern were not significant, indicating that the considered soil properties did not affect the physiological abilities of the soil microbial communities (data not shown). The ANOSIM confirmed the similarity of CLPPs under all the studied pine forests in the $\mathrm{O}$ soil horizon (Table 3).

For the A horizon, the first two CCA axes explained, respectively, $64.0 \% \quad(p=0.0020)$ and $21.3 \%$ ( $p=0.0339)$ of the variance in CLPPs and the environmental data (Fig. 3). The first CCA axis was strongly negatively related to DOC content $(-0.92)$, and the concentrations of $\mathrm{N}(-0.75)$ and $\mathrm{P}(-0.70)$, whereas the second axis was strongly negatively related to $\mathrm{pH}(-0.52)$, C-to-P (-0.46) and C-to-N (-0.45) ratio.

The BP soils were clearly separated from the temperate pine forests along the first CCA axis (Fig. 3). The two temperate pine forests were also divided along the first axis; however, the separation was less distinct (Fig. 3). The analysis of the CCA triplot indicated a strong positive relationship between the DOC and $\mathrm{N}$ content in the soil and the use of L-arginine, L-lysine and L-proline. A negative effect of high DOC and $\mathrm{N}$ was observed for the use of D-malic acid, oxalic acid, $\alpha$-ketoglutaric acid and L-ascorbic acid. The use of D-glucose was positively, and the use of D-glucosamine hydrochloride negatively, related to soil pH (Fig. 3).

The ANOSIM analysis indicated the differences in CLPPs between the BP soil microorganisms and both temperate pine forests in the A soil horizon to be statistically significant (Table 3). The SIMPER analysis revealed that the largest contribution to the average dissimilarity was from the utilisation of four carboxylic acids (D-malic, oxalic, L-ascorbic and $\alpha$-ketoglutaric acid) and two amino acids (L-Arginine and L-Lysine) (Table 4). Boreal pine forest soil microorganisms used relatively more carboxylic acids but were less efficient in using other $\mathrm{C}$ substrates, in particular amino acids. Comparison of the $\mathrm{C}$ substrate use expressed in $\mu \mathrm{g} \mathrm{C}-\mathrm{CO}_{2} \mathrm{~g}^{-1} \mathrm{~h}^{-1}$ (Table 4) indicated that only the carboxylic acids were decomposed at the similar rate in boreal and temperate soils. Decomposition of all the other $\mathrm{C}$ substrates was distinctly lower in the boreal forest soils.
Table 1 Mean values $(n=5)$ for texture of the studied boreal (BP), dry temperate (TDP) and mesic temperate pine (TMP) forest soils (standard deviations in parentheses)

\begin{tabular}{llll}
\hline Forest & Sand $(2.0-0.05 \mathrm{~mm})(\%)$ & Silt $(0.05-0.002 \mathrm{~mm})(\%)$ & Clay $(<0.002 \mathrm{~mm})(\%)$ \\
\hline BP & $81.0 \mathbf{a}(6.4)$ & $14.8 \mathbf{b}(7.5)$ & $4.2(1.1)$ \\
TDP & $93.3 \mathbf{b}(1.9)$ & $5.2 \mathbf{a}(2.2)$ & $1.6(2.3)$ \\
TMP & 87.5 ab $(3.5)$ & $9.8 \mathbf{~ a b}(4.0)$ & $2.6(1.8)$ \\
\hline
\end{tabular}

Significant differences (one-way ANOVA with Tukey's HSD test, $p=0.05$ ) between the studied forests are indicated by different letters 


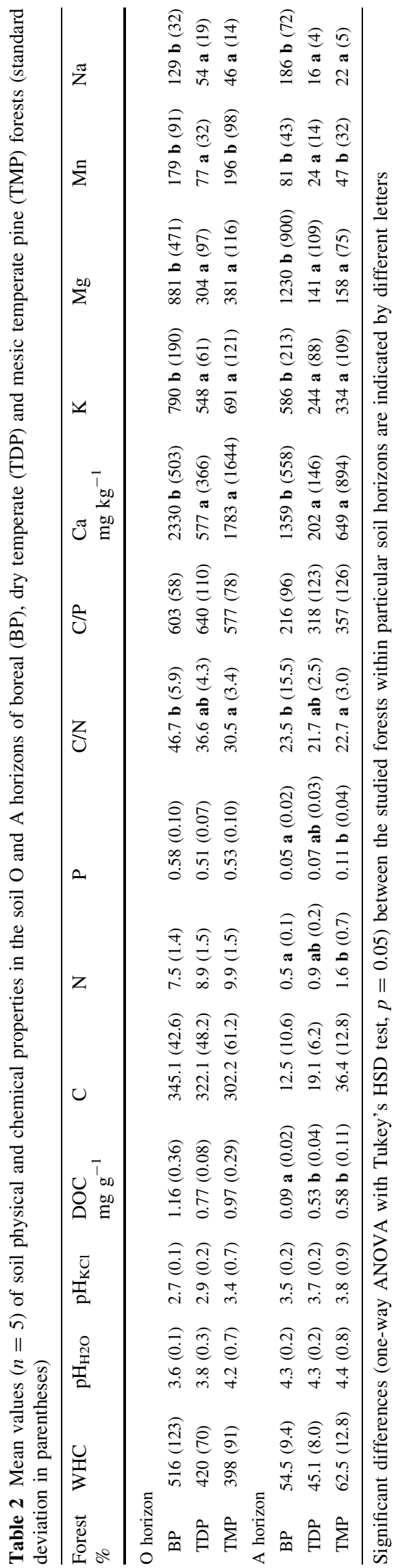

\section{Discussion}

\section{Physical and chemical soil characteristics}

The boreal pine forests grew on finer textured soils classified as loamy sands, whereas the temperate pine forests grew on sands. In particular, the dry pine forest soils in the temperate zone were characterised by a low content of fine particles (silt and clay). The studied boreal soils contained a higher level of nutrients ( $\mathrm{Ca}, \mathrm{K}, \mathrm{Mg}, \mathrm{Mn}$ and $\mathrm{Na}$ ) than the temperate forest soils, resulting apparently from the bedrock properties. The soils of Oulanka developed from glaciofluvial deposits that contain volcanic rocks and carbonates (Koutaniemi 1979) and therefore have appreciable amounts of major and trace elements (Koutaniemi et al. 1988). In Poland, the natural pine forests occur mainly on poor postglacial soils, since on more fertile sites, the Scots pine has been outcompeted by broadleaved species.

All the studied soils were acidic, wherein lower $\mathrm{pH}$ values were measured in the $\mathrm{O}$ horizon than in the underlying mineral soil. Coniferous tree species are known to produce slow decomposing litter, rich in acid compounds, and to bring about soil acidification (Hansson et al. 2011; Mueller et al. 2012). Low soil pH may reduce microbial activity, leading to large accumulation of organic matter in the $\mathrm{O}$ horizon typical for mor-type humus (Klaminder et al. 2008; Mueller et al. 2012) and is one of the most important factors leading to development of podzol soils (Koutaniemi et al. 1988). In line with our results, Degórski (2007) reported low pH values in A and deeper soil horizons under pine forests in northern and central Europe, and concluded that soil $\mathrm{pH}$ was not related to geographic location. The $\mathrm{N}$ contents were slightly lower in the boreal forest soils than in the temperate forest soils. This was probably due to lower $\mathrm{N}_{2}$ fixation and atmospheric deposition in the boreal zone compared to the temperate zone (Cleveland et al. 1999; Korhonen et al. 2013).

The DOC content in the $\mathrm{O}$ horizon was similar in all the studied forests. However, in the A horizon of boreal forest soils, the DOC content was lower than in the temperate forest soils. It is well known that organic matter accumulated in the $\mathrm{O}$ horizon is a major source of DOC, and that the DOC content decreases the soil profile downwards (Kalbitz et al. 2000). The concentration of DOC in soils depends largely on the quality of accumulated organic matter, which in turn is determined by the dominant vegetation (Kalbitz et al. 2000). Our study included only pine forests, and this explains the similar contents of DOC in the $\mathrm{O}$ horizons of the studied soils. In deeper soil horizons, the concentrations of DOC decrease mainly due to adsorption to mineral surfaces (Jardine et al. 1989; Kalbitz 
Fig. 2 Mean values $(n=5)$ of multiple substrate-induced respiration (MSIR) and Shannon-Wiener indices based on MicroResp ${ }^{\mathrm{TM}}$ data $\left(\mathrm{H}_{\text {mic }}\right.$ ) in the $\mathrm{O}$ and $\mathrm{A}$ horizons of the boreal (BP), dry temperate (TDP) and mesic temperate pine (TMP) forest soils. Whiskers indicate standard deviations

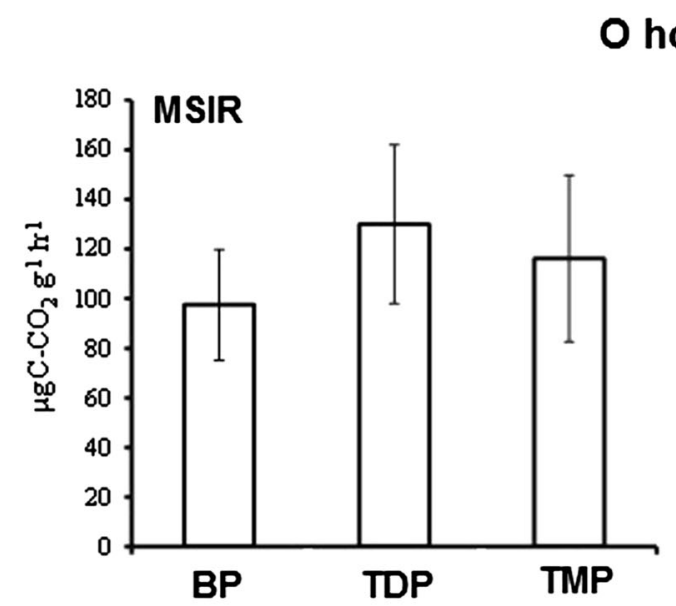

O horizon

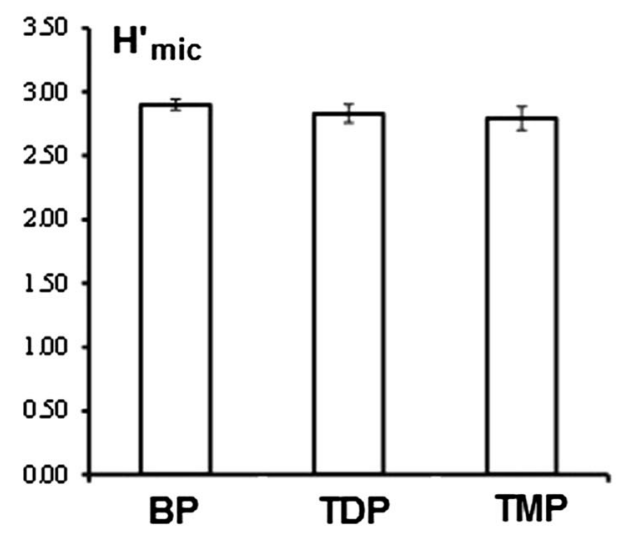

A horizon

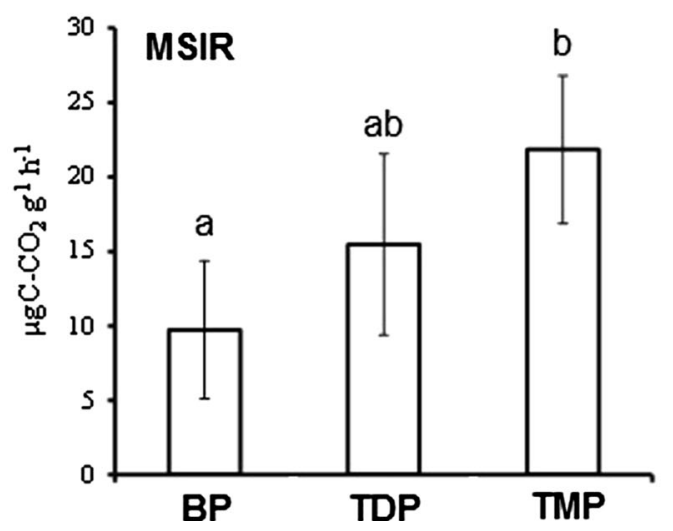

Table 3 ANOSIM for CLPPs for the O and A soil horizons

O horizon

\begin{tabular}{llr}
\hline Global $R=0.0062(p=0.4335)$ & \\
\hline Forest & TDP & TMP \\
\hline BP & $0.024(0.3881)$ & $0.148(0.1405)$ \\
TDP & & $-0.176(0.9218)$ \\
\hline
\end{tabular}

A horizon

Global $R=0.4653(p=0.0004)$

\begin{tabular}{llr}
\hline Forest & TDP & \multicolumn{1}{l}{ TMP } \\
\hline BP & $\mathbf{0 . 7 0 0 ( \mathbf { 0 . 0 0 8 } )}$ & $\mathbf{0 . 7 9 6}(\mathbf{0 . 0 0 7 1})$ \\
TDP & & $-0.014(0.4563)$
\end{tabular}

Presented are the R-values and their significance ( $\mathrm{p}$ values according to sequential Bonferroni correction) in parentheses. For each soil horizon, global $\mathrm{R}$ and its significance level are also given. The significantly different pairs are in bold

et al. 2000). Since clay minerals are important adsorbents for DOC in soils (Jardine et al. 1989; Kalbitz et al. 2000), we presume that lower DOC content in the studied boreal forest soils was due to their higher clay content. Lower DOC in the boreal soils might have resulted from climatic conditions. Kalbitz et al. (2000) reported that higher temperatures, freeze-thaw cycles and wet-dry cycles increase DOC content in soil.

\section{Microbial properties of the studied soils}

The measured microbial properties in the soil $\mathrm{O}$ horizons did not differ between the studied forests. In all the forests, the microbial activity (MSIR) and functional diversity $\left(\mathrm{H}^{\prime}{ }_{\text {mic }}\right)$ in the $\mathrm{O}$ soil horizons were at nearly the same level and the CLPPs were similar. The vegetation influences soil microorganisms by affecting the chemical and physical properties of the soil. Among these properties, soil $\mathrm{pH}$ and the content of readily available $\mathrm{C}$ have been described as a major control on the taxonomic and functional structure of soil microbial communities (Rousk et al. 2010; Kuramae et al. 2012; Tripahti et al. 2012; Chodak et al. 2013). In our study, the $\mathrm{O}$ soil horizons were characterised by similar $\mathrm{pH}$ and DOC content. In consequence, there was no factor to bring about development of functionally different soil microbial communities. The differences in other chemical 

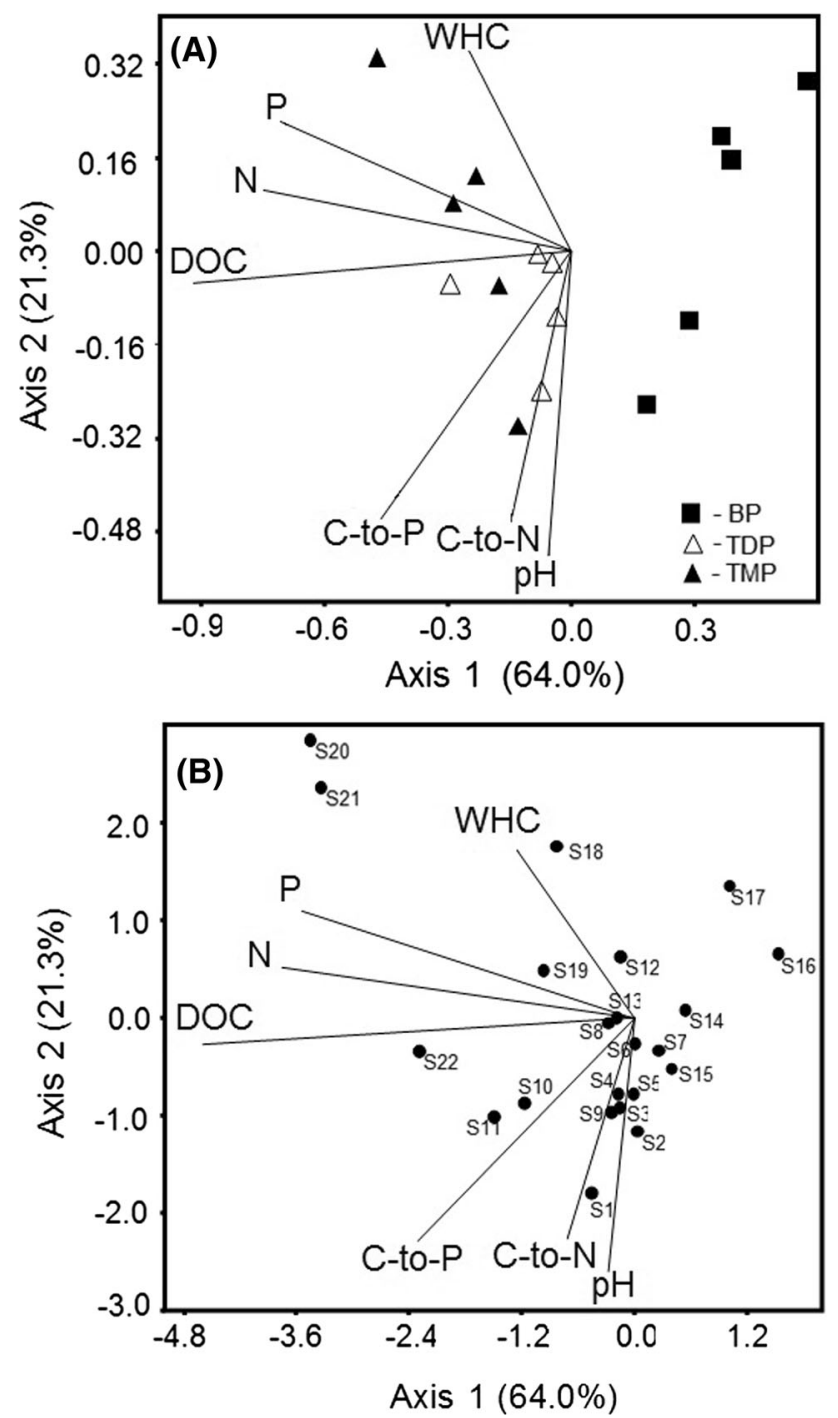

Fig. 3 Canonical correspondence analysis (CCA) ordination plot (a) of the functional microbial community structure in the A soil horizons of the boreal (BP), dry temperate (TDP) and mesic temperate pine (TMP) forest soils, and the plot of the use of different $C$ substrates in relation to chemical properties of the A horizon (b). Soil properties include: soil $\mathrm{pH}$ in $\mathrm{KCl}(\mathrm{pH})$, contents of organic dissolved organic $\mathrm{C}$ (DOC), total $\mathrm{N}$ and $\mathrm{P}$, the $\mathrm{C}$-to- $\mathrm{N}$ and $\mathrm{C}$-to-P ratios and the maximum water-holding capacity (WHC). The $\mathrm{C}$ substrates are: $\mathrm{S} 1$ : D-glucose, S2: D-fructose, S3: D-galactose, S4: D-maltose, S5: D-xylose, S6: D-arabinose, S7: D-mannose, S8: D-ribose, S9: D-cellobiose, S10: $\alpha$-cyclodextrin, S11: $\gamma$-aminobutyric acid, S12: 3-4-dihydroxybenzoic acid, S13: N-acetyl D-glucosamine, S14: $\alpha$ ketoglutaric acid, S15: L-ascorbic acid, S16: D-malic acid, S17: Oxalic acid, S18: D-glucosamine hydrochloride, S19: L-alanine, S20: L-arginine, S21: L-lysine and S22: L-proline

soil properties (e.g. C-to- $\mathrm{N}$ ratio, the contents of $\mathrm{Ca}, \mathrm{Mg}$ and $\mathrm{K}$ ) between the studied forest soils apparently did not lead to the development of functionally different microbial communities.

For the A horizon, the measured microbial properties differed between the forest stands, with the boreal forest soil showing the lowest values of MSIR and $\mathrm{H}^{\prime}$ mic and distinctly different CLPPs than the temperate forests. The SIR is a method of biomass determination (Anderson and Domsch 1978); therefore, the MSIR may be regarded as a proxy of soil microbial biomass (Creamer et al. 2016). Lower MSIR values, indicative of lower microbial biomass in boreal pine forest soils, may be explained by lower contents of C, DOC, N and P in these soils. The microbial biomass in soils depends strongly on the energy source $(\mathrm{C}$, DOC) and the content of essential nutrients such as $\mathrm{N}$ and $\mathrm{P}$ (Gallardo and Schlesinger 1994; Alden et al. 2001; Allen and Schlesinger 2004; Demoling et al. 2007). It is considered that up to a certain threshold, an increase in microbial biomass also induces an increase in functional diversity (Lynch et al. 2004). Accordingly, larger microbial communities in the temperate forest soils were characterised by higher functional diversity than those from the boreal forest soils.

The analysis of CLPPs indicated that microbial communities in the soil A horizons of boreal forests used carboxylic acids effectively but were less efficient in respiring other $\mathrm{C}$ substrates, in particular amino acids. In the temperate forest soils, the use of added $\mathrm{C}$ substrates was more uniform. Although the carboxylic acids were degraded very rapidly in the temperate forest soils, the metabolisation of amines and sugars was only slightly less efficient. Furthermore, the soil microbial communities in the temperate forests decomposed amino acids more effectively than those in the boreal forest soils. The results of CCA analysis underlined the importance of readily available $\mathrm{C}$ and nutrient contents for the functional structure of the soil microbial communities, as the CLPPs to the largest extent depended on the contents of DOC, N and P. The DOC represents a mobile and readily available fraction of soil organic matter (Zsolnay 1996), although the proportion of the labile part of DOC is highly variable (Zsolnay and Steindl 1991).

The metabolic abilities of soil microbial communities are likely to reflect the composition and bioavailability of soil organic matter (Orwin et al. 2006; Banning et al. 2012). Thus, high use of carboxylic acids suggests that although these compounds correspond to a minor fraction of the DOC (Van Hees et al. 2002), they constitute an important energy source for soil microbes. Carboxylic acids are involved in several soil processes and are intensively exuded by plant roots in low $\mathrm{pH}$ soils and under $\mathrm{P}$ deficiency (Jones 1999), such as in our study. Significantly higher relative use of carboxylic acids in the soil A horizons of boreal forests suggests that in these soils, carboxylic acids may constitute a larger fraction of readily available $\mathrm{C}$. This may result from higher exudation of carboxylic acids by plant roots and ectomycorrhizal fungi in the boreal forest soils. These soils contained less $\mathrm{P}$ than 
Table 4 Results of SIMPER analysis for CLPPs in the soil A horizons under boreal (BP), dry temperate (TDP) and mesic temperate pine (TMP) forests

\begin{tabular}{|c|c|c|c|c|c|c|c|c|}
\hline \multirow[t]{2}{*}{ Substrate } & \multicolumn{2}{|l|}{ Dissimilarity measure } & \multicolumn{3}{|c|}{$\begin{array}{l}\text { Relative use of substrate } \\
(\%)\end{array}$} & \multicolumn{3}{|c|}{$\operatorname{SIR}\left(\mu \mathrm{g} C-\mathrm{CO}_{2} \mathrm{~g}^{-1} \mathrm{~h}^{-1}\right)$} \\
\hline & Average dissimilarity & Contribution (\%) & BP & TDP & TMP & BP & TDP & TMP \\
\hline D-Malic acid & 3.6 & 16.2 & 17.8 & 8.3 & 7.5 & $1.55(0.61)$ & $1.21(0.27)$ & $1.64(0.47)$ \\
\hline Oxalic acid & 2.4 & 11.1 & 13.0 & 7.6 & 7.4 & $1.16(0.65)$ & $1.12(0.35)$ & $1.61(0.42)$ \\
\hline L-Ascorbic acid & 1.2 & 5.6 & 9.4 & 8.3 & 6.9 & $0.97(0.55)$ & $1.22(0.32)$ & $1.49(0.37)$ \\
\hline$\alpha$-Ketoglutaric acid & 1.2 & 5.3 & 8.1 & 5.7 & 5.5 & $0.88(0.55)$ & $0.89(0.36)$ & $1.18(0.28)$ \\
\hline L-Arginine & 1.1 & 5.1 & 0.0 & 1.4 & 3.2 & $0.00(0.00)$ & $0.26(0.33)$ & $0.65(0.26)$ \\
\hline L-Lysine & 1.1 & 5.0 & 0.0 & 1.3 & 3.2 & $0.00(0.00)$ & $0.24(0.27)$ & $0.66(0.25)$ \\
\hline D-Glucose & 1.1 & 4.8 & 3.8 & 5.2 & 5.2 & $0.39(0.35)$ & $0.82(0.39)$ & $1.21(0.61)$ \\
\hline L-Alanine & 1.0 & 4.5 & 2.5 & 4.8 & 4.5 & $0.26(0.20)$ & $0.71(0.19)$ & $0.96(0.28)$ \\
\hline L-Proline & 0.9 & 4.2 & 0.0 & 2.9 & 2.6 & $0.01(0.02)$ & $0.44(0.18)$ & $0.55(0.09)$ \\
\hline D-Glucosamine hydrochloride & 0.9 & 4.1 & 3.5 & 3.9 & 5.2 & $0.34(0.19)$ & $0.60(0.22)$ & $1.05(0.43)$ \\
\hline D-Fructose & 0.9 & 4.0 & 5.0 & 5.3 & 4.6 & $0.49(0.33)$ & $0.82(0.39)$ & $1.03(0.40)$ \\
\hline$\gamma$-Aminobutyric acid & 0.9 & 3.9 & 0.6 & 2.9 & 2.9 & $0.07(0.05)$ & $0.45(0.18)$ & $0.64(0.22)$ \\
\hline D-Cellobiose & 0.8 & 3.5 & 3.5 & 4.4 & 4.6 & $0.34(0.16)$ & $0.70(0.35)$ & $1.02(0.45)$ \\
\hline$\alpha$-Cyclodextrin & 0.7 & 3.2 & 1.0 & 2.8 & 3.0 & $0.11(0.06)$ & $0.44(0.18)$ & $0.66(0.22)$ \\
\hline N-acetyl D-glucosamine & 0.7 & 3.0 & 4.1 & 5.3 & 4.1 & $0.42(0.24)$ & $0.85(0.43)$ & $0.87(0.16)$ \\
\hline Protocatechuic acid & 0.7 & 3.0 & 4.2 & 4.4 & 4.3 & $0.45(0.32)$ & $0.68(0.28)$ & $0.90(0.10)$ \\
\hline D-Maltose & 0.6 & 2.6 & 4.0 & 4.2 & 4.9 & $0.41(0.24)$ & $0.64(0.24)$ & $1.10(0.44)$ \\
\hline D-Mannose & 0.5 & 2.4 & 5.0 & 4.7 & 4.6 & $0.48(0.21)$ & $0.74(0.33)$ & $1.03(0.38)$ \\
\hline D-Galactose & 0.5 & 2.3 & 3.7 & 4.1 & 4.2 & $0.38(0.25)$ & $0.63(0.28)$ & $0.94(0.37)$ \\
\hline D-Xylose & 0.5 & 2.2 & 4.1 & 4.6 & 4.3 & $0.40(0.19)$ & $0.73(0.37)$ & $0.98(0.39)$ \\
\hline D-Arabinose & 0.5 & 2.1 & 3.8 & 4.2 & 3.9 & $0.36(0.15)$ & $0.70(0.43)$ & $0.90(0.42)$ \\
\hline D-Ribose & 0.4 & 1.9 & 2.8 & 3.7 & 3.4 & $0.27(0.11)$ & $0.59(0.29)$ & $0.78(0.32)$ \\
\hline
\end{tabular}

The term 'Contribution' represents the contribution of a substrate to the average dissimilarity in CLPP between the forests. 'Contribution \%' is

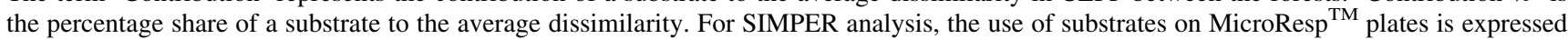
as relative \%. Substrate-induced respiration (SIR) values corrected for basal respiration for particular substrates are also given (mean value and standard deviation in parentheses, $n=5$ )

the temperate forest soils, and it is known that low availability of soil P may stimulates the release of carboxylic acids both by plants and ectomycorrhizal fungi. Malic acid is one of the primary organic components released by plant roots at P deficiency (Jones and Darah 1994; Jones 1998), whereas for ectomycorrhizal fungi, the release of the oxalic acid has been suggested as an important mechanism of $\mathrm{P}$ solubilisation (Ahonen-Jonnarth et al. 2000). These two acids were preferably metabolised by the boreal forest soil microbial communities.

The lower decomposition of amino acids in the boreal forest soils apparently resulted from their lower $\mathrm{N}$ content. Both carboxylic and amino acids represent rapidly decomposable organic compounds (Jones 1998, 1999; van Hees et al. 2002). However, amino acids are mostly used for microbial biomass build-up, whereas carboxylic acids are mostly used for respiration (Jones 1999). We presume that in N-poor boreal forest soils, a larger proportion of amino acids was assimilated for microbial biomass build- up and only a smaller proportion for respiration. In the temperate forest soils characterised by higher $\mathrm{N}$ content and narrower $\mathrm{C}$-to- $\mathrm{N}$ ratios, a larger part of the added amino acids was used for respiration and a smaller part was assimilated for biomass production.

The MicroResp ${ }^{\mathrm{TM}}$ method has been developed to enable physiological profiling of whole soil microbial communities without the need for their extraction and culture (Campbell et al. 2003). However, one should bear in mind that the MicroResp ${ }^{\mathrm{TM}}$ method is a short-term assay and its results may refer not to the whole soil microbial community, represented by many different groups of soil microorganisms occurring in varying proportions, i.e. plant-associated mycorrhizal fungi, litter-decomposing fungi (asco- and basidiomycetes), wood-decomposing fungi, 'free-living' bacteria, root- and hyphal-associated bacteria and different kinds of pathogens etc., but to microorganisms capable of a rapid response to added $\mathrm{C}$ substrates. Despite this flaw of the MicroResp ${ }^{\mathrm{TM}}$ test, the 
application of this method did provide relevant information on the metabolic preferences of soil microbial communities in boreal and temperate Scots pine forest soils.

\section{Conclusions}

In the $\mathrm{O}$ horizons, the activity and the functional diversity and structure of microbial communities were similar in all the studied pine forests suggesting that, in this horizon, the dominating tree species (pine) is the most important control on microbial properties. However, in the A horizon of boreal forest soils, the microbial communities were less active, less functionally diverse and exhibited different functional profiles than those under the temperate forests. The functional differences were related to the contents of DOC, $\mathrm{N}$ and $\mathrm{P}$ which are affected by climate, geographic location and bedrock properties. Our results suggest that soil microbial properties in the deeper soil layers depend to a larger extent on climatic conditions and bedrock properties.

Acknowledgments The study was supported by the Grant from the Polish National Science Centre (00421/NZ8/2012/29) and also partially by funds from the European Union Seventh Framework Programme [FP7/2007-2013] under Grant agreement $n^{\circ} 262693$ [INTERACT] and from Jagiellonian University (subsidy WBiNoZ/ INoS/DS758).

Open Access This article is distributed under the terms of the Creative Commons Attribution 4.0 International License (http://crea tivecommons.org/licenses/by/4.0/), which permits unrestricted use, distribution, and reproduction in any medium, provided you give appropriate credit to the original author(s) and the source, provide a link to the Creative Commons license, and indicate if changes were made.

\section{References}

Ahonen-Jonnarth U, Van Hees PAW, Lundström US, Finlay RD (2000) Organic acids produced by mycorrhizal Pinus sylvestris exposed to elevated aluminium and heavy metal concentrations. New Phytol 146:557-567

Alden L, Demoling F, Bååth E (2001) Rapid method of determining factors limiting bacterial growth in soil. Appl Environ Microbiol 67:1830-1838

Allen AS, Schlesinger WH (2004) Nutrient limitations to soil microbial biomass and activity in loblolly pine forests. Soil Biol Biochem 36:581-589

Anderson JPE, Domsch KH (1978) A physiological method for the quantitative measurement of microbial biomass in soils. Soil Biol Biochem 10:215-221

Attiwill PM, Adams MA (1993) Nutrient cycling in forests. New Phytol 124:561-582

Banning NC, Lalor BM, Cookson WR, Grigg AH, Murphy DV (2012) Analysis of soil microbial community level physiological profiles in native and post-mining rehabilitation forest: Which substrates discriminate? Appl Soil Ecol 56:27-34
Bauhus J, Khanna PK (1999) The significance of microbial biomass in forest soils. In: Rastin N, Bauhus J (eds) Going undergroundecological studies in forest soils. Research Signpost, Trivandrum

Bauhus J, Paré D, Côté L (1998) Effects of tree, stand age and soil type on soil microbial biomass and its activity in a southern boreal forest. Soil Biol Biochem 30:1077-1089

Boratyński A (1991) Range of natural distribution. In: Giertych M, Matyas C (eds) Genetics of Scots pine developments in plant genetics and breeding, 3. Elsevier, Amsterdam

Campbell CD, Chapman SJ, Cameron CM, Davidson M, Potts JM (2003) A rapid microtiter plate method to measure carbon dioxide evolved from carbon substrate amendments so as to determine the physiological profiles of soil microbial communities by using whole soil. Appl Environ Microbiol 69:3593-3599

Casagrande A (1934) Die Areometr Methode zur Bestimmung der Kornverteilung von Böden. Springer, Berlin

Chodak M, Gołębiewski M, Morawska-Płoskonka J, Kuduk K, Niklińska M (2013) Diversity of microorganisms from forest soils differently polluted with heavy metals. Appl Soil Ecol 64:7-14

Clarke KR (1993) Non-parametric multivariate analyses of changes in community structure. Aust J Ecol 18:117-143

Clarke KR, Green RH (1988) Statistical design and analysis for a "biological effects"' study. Mar Ecol Prog Ser 46:213-226

Cleveland CC, Townsend AR, Schimel DS, Fisher H, Howarth RW, Hedin LO, Perakis SS, Latty EF, Von Fischer JC, Elseroad A, Wasson MF (1999) Global patterns of terrestrial biological nitrogen $\left(\mathrm{N}_{2}\right)$ fixation in natural ecosystems. Global Biogeochem Cycles 13:623-645

Creamer RE, Stone D, Berry P, Kuiper I (2016) Measuring respiration profiles of soil microbial communities across Europe using MicroResp ${ }^{\mathrm{TM}}$ method. Appl Soil Ecol 97:36-43

Degórski M (2007) Spatial variability in podzolic soils of Central and Northern Europe. Office of Research and Development U.S. Environmental Protection Agency, Washington

Demoling F, Figueroa D, Bååth E (2007) Comparison of factors limiting bacterial growth in different soils. Soil Biol Biochem 39:2485-2495

Derry AM, Staddon WJ, Kevan PG, Trevors JT (1999) Functional diversity and community structure of micro-organisms in three arctic soils as determined by sole-carbon-source-utilization. Biodivers Conserv 8:205-221

Evans SE, Wallenstein MD (2014) Climate change alters ecological strategies of soil bacteria. Ecol Lett 17:155-164

Finlay RD (2008) Ecological aspects of mycorrhizal symbiosis: with special emphasis on the functional diversity of interactions involving the extraradical mycelium. J Exp Bot 59:1115-1126

Gallardo A, Schlesinger WH (1994) Factors limiting microbial biomass in the mineral soil and forest floor of a warm-temperate forest. Soil Biol Biochem 26:1409-1415

Garcia-Pausas J, Paterson E (2011) Microbial community abundance and structure are determinants of soil organic matter mineralisation in the presence of labile carbon. Soil Biol Biochem 43:1705-1713

Gartzia-Bengoetxea N, Kandeller E, de Arano IM, Arias-González A (2016) Soil microbial functional activity is governed by a combination of tree species composition and soil properties in temperate forests. Appl Soil Ecol 100:57-64

Grayston SJ, Campbell CD, Bardgett RD, Mawdsley JL, Clegg SD, Ritz K, Griffiths BS, Rodwell JS, Edwards SJ, Davies WJ, Elston DJ, Millard P (2004) Assessing shifts in microbial community structure across a range of grass-lands of differing management intensity using CLPP, PLFA and community DNA techniques. Appl Soil Ecol 25:63-84 
Hackl E, Pfeffer M, Donat C, Bachmann G, Zechmeister-Boltenstern $S$ (2005) Composition of the microbial communities in the mineral soil under different types of natural forest. Soil Biol Biochem 37:661-671

Hansson K, Olsson BA, Olsson M, Johansson U, Kleja DB (2011) Differences in soil properties in adjacent stands of Scots pine, Norway spruce and silver birch in SW Sweden. For Ecol Manag 262:522-530

Heinonsalo J, Jørgensen KS, Sen R (2001) Microcosm-based analyses of Scots pine seedling growth, ectomycorrhizal fungal community structure and bacterial carbon utilization profiles in boreal forest humus and underlying illuvial mineral horizons. FEMS Microbiol Ecol 36:73-84

Högberg MN, Högberg P (2002) Extramatrical ectomycorrhizal mycelium contributes one-third of microbial biomass and produces, together with associated roots, half the dissolved organic carbon in a forest soil. New Phytol 154:791-795

Jardine PM, Weber NL, McCarthy JF (1989) Mechanism of dissolved organic carbon adsorption on soil. Soil Sci Soc Am J 53:1378-1385

Jones D (1998) Organic acids in the rhizosphere-a critical review. Plant Soil 205:25-44

Jones D (1999) Amino acid biodegradation and its potential effects on organic nitrogen capture by plants. Soil Biol Biochem 31:613-622

Jones D, Darah PR (1994) Role of root derived organic acids in the mobilization of nutrients from the rhizosphere. Plant Soil 166:247-257

Kalbitz K, Solinger S, Park J-H, Michalzik B, Matzner E (2000) Controls on the dynamics of dissolved organic matter in soils: a review. Soil Sci 165:277-304

Kelly DL, Conolly A (2000) A review of the plant communities associated with Scots pine (Pinus sylvestris L.) in Europe, and an evaluation of putative indicator/specialist species. For Syst 9:15-39

Kiikkilä O, Kitunen V, Smolander A (2006) Dissolved soil organic matter from surface organic horizons under birch and conifers: degradation in relation to chemical characteristics. Soil Biol Biochem 38:737-746

Klaminder J, Bindler R, Rydberg J, Renberg I (2008) Is there a chronological record of atmospheric mercury and lead deposition preserved in the mor layer (O-horizon) of boreal forest soils? Geochim Cosmochim A 72:703-712

Korhonen JFJ, Pihlatie M, Pumpanen J, Aaltonen H, Hari P, Levula J, Kieloaho A-J, Nikinmaa E, Vesala T, Ilvesniemi H (2013) Nitrogen balance of a boreal Scots pine forest. Biogeosciences 10:1083-1095

Koutaniemi L (1979) Late-glacial and post-glacial development of the valleys of the Oulanka river basin, north-eastern Finland. Fennia 157:13-67

Koutaniemi L, Koponen R, Rajanen K (1988) Podzolization as studied from terraces of various ages in two river valleys, Northern Finland. Silva Fennica 22:113-133

Kuramae EE, Yergeau E, Wong LC, Pijl AS, van Veen JA, Kowalchuk GA (2012) Soil characteristics more strongly influence soil bacterial communities than land-use type. FEMS Microbiol Ecol 79:12-24

Ladygina N, Hedlund K (2010) Plant species influence microbial diversity and carbon allocation in the rhizosphere. Soil Biol Biochem 42:162-168

Leski T, Aučina A, Skridaila A, Pietras M, Riepšas E, Rudawska M (2010) Ectomycorrhizal community structure of different genotypes of Scots pine under forest nursery conditions. Mycorrhiza 20:473-481

Lynch JM, Benedetti A, Insam H, Nuti MP, Smalla K, Torsvik V, Nannipieri P (2004) Microbial diversity in soil: ecological theories, the contribution of molecular techniques and the impact of transgenic plants and transgenic microorganisms. Biol Fertil Soils 40:363-385

Matías L, Jump AS (2012) Interactions between growth, demography and biotic interactions in determining species range limits in a warming world: the case of Pinus sylvestris. Forest Ecol Manag 282:10-22

Matuszkiewicz W (2006) Przewodnik do oznaczania zbiorowisk roślinnych Polski [in Polish] (Handbook of forest assemblages identification). Wydawnictwo Naukowe PWN, Warszawa

McIntosh ACS, Macdonald SE, Quideau SA (2013) Linkages between the forest floor microbial community and resource heterogeneity within mature lodgepole pine forests. Soil Biol Biochem 63:61-72

Menyailo OV, Hungate BA, Zech W (2002) Tree species mediated soil chemical changes in a Siberian artificial Afforestation experiment. Plant Soil 242:171-182

Mueller KE, Eissenstat DM, Hobbie SE, Oleksyn J, Jagodzinski OM, Reich PB, Chadwick OA, Chorover J (2012) Tree species effects on coupled cycles of carbon, nitrogen, and acidity in mineral soils at a common garden experiment. Biogeochemistry 111:601-614

Orwin KH, Wardle DA, Greenfield LG (2006) Ecological consequences of carbon substrate identity and diversity in a laboratory study. Ecology 97:580-593

Priha O, Grayston SJ, Hiukka R, Pennanen T, Smolander A (2001) Microbial community structure and characteristics of the organic matter under Pinus sylvestris, Picea abies and Betula pendula at two forest sites. Biol Fertil Soils 33:17-24

Rousk J, Bååth E, Brookes PC, Lauber CL, Lozupone C, Caporaso JG, Knight R, Fierer N (2010) Soil bacterial and fungal communities across a $\mathrm{pH}$ gradient in an arable soil. ISME J 4:1340-1351

Schlichting E, Blume HO (1966) Bodenkundliches Praktikum. Paul Parey, Hamburg

Sherman C, Steinberger Y (2012) Microbial functional diversity associated with plant litter decomposition along a climatic gradient. Microb Ecol 64:399-415

Sradnick A, Murugan R, Oltmanns M, Raupp J, Joergensen RG (2013) Changes in functional diversity of the soil microbial community in a heterogeneous sandy soil after long-term fertilization with cattle manure and mineral fertilizer. Appl Soil Ecol 63:23-28

ter Braak CJF (1987) Ordination. In: Jongman RH, ter Braak CJF, van Tongeren OFR (eds) Data analysis in community and landscape ecology. Center for Agricultural Publishing And Documentation, Wageningen, pp 91-169

Thoms C, Gattinger A, Jacob M, Thomas FM, Gleixner G (2010) Direct and indirect effects of tree diversity drive soil microbial diversity in temperate deciduous forest. Soil Biol Biochem 42:1558-1565

Tonteri T, Hotanen J-P, Kuusipalo J (1990) The Finnish forest site type approach: ordination and classification studies of mesic forest sites in southern Finland. Vegetatio 87:85-98

Tripahti BM, Kim M, Singh D, Lee-Cruz L, Lai-Hoe A, Ainuddin AN, Go R, Rahim RA, Husni MH, Chun J, Adams JM (2012) Tropical soil bacterial communities in Malaysia: $\mathrm{pH}$ dominates in the equatorial tropics too. Microb Ecol 64:474-484

Van Breemen N, Finlay R, Lundström U, Jongmans AG, Giesler R, Olsson M (2000) Mycorrhizal weathering: A true case of mineral plant nutrition? Biogeochemistry 49:53-67

Van Hees PAW, Jones DL, Godbold DL (2002) Biodegradation of low molecular weight organic acids in coniferous forest podzolic soils. Soil Biol Biochem 34:1261-1272

Wardle DA, Bardgett RD, Klironomos JN, Setala H, Van der Putten WH, Wal DH (2004) Ecological linkages between aboveground and belowground biota. Science 304:1625-1633 
Zak JC, Willig MR, Moorhead DL, Wildman HD (1994) Functional diversity of microbial communities: a quantitative approach. Soil Biol Biochem 26:1101-1108

Zechmeister-Boltenstern S, Michel K, Pfeffer M (2011) Soil microbial community structure in European forests in relation to forest type and atmospheric nitrogen deposition. Plant Soil 343:37-50
Zsolnay A (1996) Dissolved humus in soil waters. In: Piccolo A (ed) Humic substances in terrestrial ecosystems. Elsevier, Amsterdam, pp 171-223

Zsolnay A, Steindl H (1991) Geovariability and biodegradability of the water-extractable organic material in an agricultural soil. Soil Biol Biochem 23:1077-1082 